inspection certificate could be issued. Most of these had or were near infestations of San José scale. To date 111 inspection certificates have been issued, 57 dealers' certificates, 96 permits to outside nurserymen and 294 agents' permits. This has kept the writer, with one assistant and one deputy, during the summer season, busy, considering the fact that we have also the college and station work to administer. We have also been busy with the shipments of foreign stock, and have begun the first of our winter demonstrations for the control of San José scale.

We feel that we have already made a slight beginning and with the continued earnest coöperation of fruit growers, nurserymen and colleagues we hope to be able to protect all home interests affected by the law, and to be of some assistance in the protecting of similar interests in other states.

\title{
PLANT-LOUSE NOTES FROM CALIFORNIA
}

By W. M. Davidson, U. S. Bureau of Entomology, Walnut Creek, Cal.1

Pemphigus californicus Davidson. Close observations on the habits of this species indicate that it migrates towards the end of April from the buttercup to the ash (Fraxinus oregona Nutt.). The third generation on the buttercup all become winged lice and forsake the plant in a body. They and their immediate progeny cause the leaves of the ash to curl in a manner similar to that caused by Pemphigus fraxini-dipetaloe Essig. In May, the shrivelled migrants may be found in the curled leaves together with the apterous lice of the second and third generations on the ash. These apterous lice have undeveloped eyes, the first generation of them being large bloated individuals. The third, or second apterous, generation on the ash is composed of both winged and wingless individuals.

Lachnus thujafalinus Del Guercio. Infests branches and twigs of cultivated Thujas. In California winged lice appear in April. Collected at Palo Alto and Walnut Creek, California.

Lachnus ponderose Williams. Observed in abundance in August, 1912, at Glenbrook, Nev., and Tallac, Cal. (elevation $6000 \mathrm{ft}$.) on twigs and branches of Pinus ponderosa var. jeffreyi Vasey.

Phyllaphis? querci Fitch. Mr. J. J. Davis has kindly identified this louse described and figured by him in the Entomological News, Vol. xxii, June, 1911. I have taken it in the fall on the under side of leaves of Quercus agrifolia Nee, the sexed forms appearing in early November. Towards the end of April, the stem mothers appear on the upper side

1 Published with the permission of the Chief of the Bureau of Entomology. 
of the leaves of $Q$. agrifolia and $Q$. lobata Nee, tightly curling over the edges of the leaf and thus forming a pseudo-gall. The second generation are wingless and remain in the gall until mature, when they leave the gall for the under side of adjoining leaves, living thenceforth unprotected except for the wooly covering characteristic of the species. I have observed this aphid in Placer, Contra Costa and Santa Clara Counties in California. In Placer Co. it infests the Interior Live Oak (Q. wislizenii A. DC.).

\section{Chaitophorus sp.}

Stem mother: Pale yellowish-green with two longitudinal light green stripes on the dorsum of thorax and abdomen. Antennæ six-jointed (filament regarded as a joint), one-quarter as long as the body, pale, first two joints slightly dusky. Eyes small and undeveloped. Legs pale, tarsi dusky. Cornicles appearing as dusky-rimmed pores
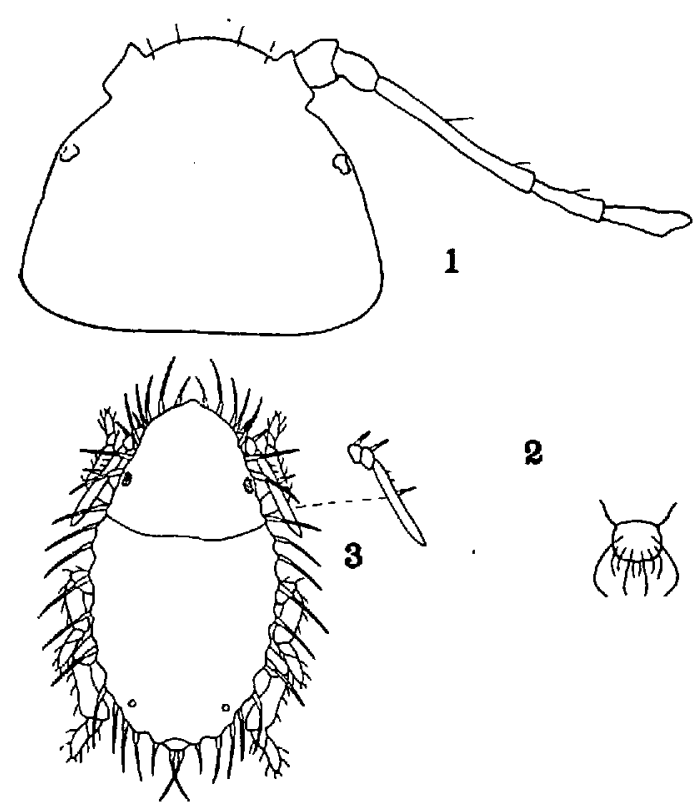

Fig. 1, Chaitophorus 1, stem mother, head; 2, stem mother, cauda; 3 , dimorph. on the surface of the body. Cauda globular, păle. Whole body except the head clothed with short, stout, erect white spines. Measurements: Body, length to tip of cauda, $2.00 \mathrm{~mm}$, ; body, width (maximum), 1.16mm.; c a u da, length, .054mm.; antennæ, joint III, .207mm.; joint IV, $.100 \mathrm{~mm}$; ; joint $\mathrm{V}, .100 \mathrm{~mm}$; filament, $.024 \mathrm{~mm}$.

Dimorph: Entirely pale yellowish-white, flabellæ hyaline. Body short, oval, very flat. Eyes black, not well developed. Antennæ threejointed, distal joint three or four times as long as the two basal combined; articulations rather obscure. Legs stout, bearing hairs. Beak pale, barely reaching second coxæ. Flabelle, long, two-jointed, sharply pointed at apex, narrow, the basal joint the broader; longest pair, .08mm.; basal joint about one-third as long as distal joint; latter easily broken off leaving basal joint with sharply pointed apex. Each antennal joint bears a flabella shorter than those of the body. Flabelle spaced almost regularly around the margin of the body, 38 in number. Cornicles short, pale, erect from the body. Cauda short and blunt.

Provisionally placed in Chaitophorus.

The stem mothers were observed April 13, 1913 on the leaves and stalks of Quercus lobata Nee. On that date they were surrounded by young of the second generation. Ten days later before any of these young had matured an invasion of Lampyrid beetles apparently 
annihilated the colony of lice, but on May 30, a few dimorphs appeared. These probably belonged to the third generation. Habitat; Walnut Creek, Cal.

\section{Euceraphis betulce Kalt.}

Stem mother: General color apple grecn. Body clothed with short bluish-white pulverulence (much less than in the winged female of later generations). Head olive green with a central black longitudinal stripe. Prothorax, thoracic lobes and scutellum, olive green. Eyes dark red. Antennæ on frontal tubercles, a little longer than the body, black (joint I, green); basal third of joint III, thickened to include about 16 transversely-oval sensoria; joints IV and V with the usual apical sensoria. Wings large and narrow; stigma long, very pale yellow; sub-costa dark brown; stigmatic vein entire and deeply curved. Legs yellowish-grcen; tarsi, apical third of tibix, apical third of middle and hind femora, brownish-black. Abdomen with almost parallel sides, not wider than the thorax; color apple green with three dusky crossbands on the dorsum. Cornicles pale yellow, almost twice as long as broad at the brse, slightly constricted in the middle. Cauda globular, concolorous with the body, slightly longer than the cornicles. Beak reaches midway between first and second coxa, pale. Sterna brown. Measurements: Body, length, $3.20 \mathrm{~mm}$.; body, maximum width, $1.11 \mathrm{~mm}$; wing expanse, $9.37 \mathrm{~mm}$.; cornicles, $.128 \mathrm{~mm}$; cauda, $.150 \mathrm{~mm}$; antenna, joint I, .157mm.; joint II, .085mm.; joint III, 1.50mm.; joint IV, .814mm.; joint $\mathrm{V}, .588 \mathrm{~mm}$.; joint VI, .205mm.; filament, .129mm.; Hind tibiæ, $2.17 \mathrm{~mm}$.

The newly-hatched stem mothers are brownish-yellow with pale yellow appendages, thus differing from those of later generations which are bright green. The pupæ of stem mothers are reddish-yellow with dusky cornicles and four longitudinal rows of dusky spots on the dorsum.

Young stem mothers were observed to hatch from winter eggs as early as the middle of February, while the leaf buds did not open until March 1, the lice feeding entirely on the stalks. In California this species occurs on cultivated birches.

\section{Eucallipterus arundicolens Clarke.}

Winged viviparous female: Pale yellow; head pinkish; eyes dark red. Head with a median dorsal brown stripe. Prothorax pale with median brown stripe, and with two lateral longitudinal brown stripes on its anterior half. Each lateral thoracic lobe with a median brown stripe. Scutellum pale with the outer ends brown. Abdomen narrow, oval, pale yellow with a pair of dark brown tubercles on segments 2 to 8 inclusive; 9 th segment with a brown median spot or stripe. Cornicles as broad as long, dark brown. Cauda pale, globular, about as long as the cornicles. Appendages; antenne about as long as the body, on frontal tubercles, pale yellow; joint I, reddish; joint II and basal half of III, dusky; apices of remaining joints and whole of filament dusky; joint III is longest; joint VI is longer than the filament; joint V is longer than VI and its filament combined; five to eight transversely-oval sensoria occur on basal third of joint III and the usual terminal are to be found on joints $\mathrm{V}$ and VI. Wings considerably exceeding the body in length; stigma, pale greenishyellow, long, narrow; stigmal vein, absent in the middle; veins, brown; second fork of third discoidal nearer to first fork than to wing apex. Legs, pale yellow throughout. Beak, reddish, reaching to first coxæ. Head on under side, reddish. Sterna yellow. Anal plate deeply lobed. The antenna alone have a white powdery covering. Meas- 
urements: Body, length, $1.97 \mathrm{~mm}$; body, width, .604mm; wing expanse, 5.6mm.; cornicles, .067mm.; cauda, .064mm.; antennæ, joint I, .088mm.; joint II, .086mm.;

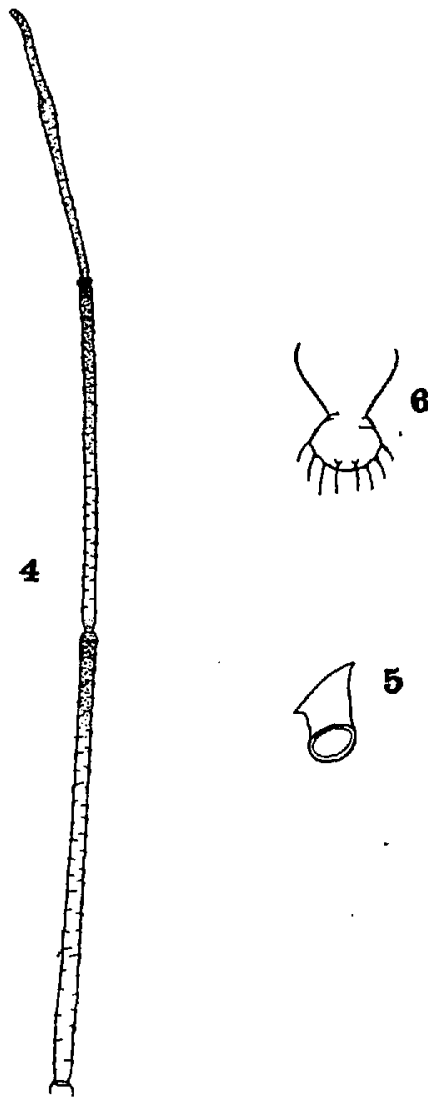

Fig. 2, Eucallipterus arundicolens; 4 , winged viviparous female, antenna; 5 , cornicle; 6 , cauda. joint III, .80mm.; joint IV, .572mm.; joint V, $.474 \mathrm{~mm}$.; joint VI, .247mm.; flament, .185mm.

Pupa: Wholly yellow with dark red eyes, and apices of antennal joints III to V brown; head with a faint reddish tinge. Antennæ longer than the body. Body spinous.

This species is to be found on the under side of leaves of Bamboos (Arundo spp.). I have never been able to collect the sexed insects.

\section{Myzocallis quercus Kalt. (?)}

Winged viviparous female: General color, pale pea green; antennæe as long as the body, pale greenish-yellow, apices of joints III to VI and whole of joints $I$ and the filament, black; joint III, longer th.an IV and V together. Thorax of slightly darker green than the abdomen. Wings long and ample; veins slender, brown; stigma, with a faint brownish cloud and with a basal black spot; stigmatic vein entire; apical cell of the wing rather small. Legs, yellow or yellowbrown; tarsi, dusky brown. Abdomen with three pairs of short dusky tubercles on the dorsum of segments one to thres inclusive; the pair on segment three about twice as long as those on segments one and two. Cornicles black, in some individuals the base is pale; as wide at the base as long, slightly tapering toward apex. Cauda, concolorous with the body; globular, not as long as the hind tarsus, but about equal in length to the cornicles. Beak, pale, tip black, extending not quite midway between first and second coxx. Sterna, pale green. Sensoria as follows: III, 7 ; IV, 0 ; V, usual apical; VI, usual apical. Measurements: Body, length, $1.78 \mathrm{~mm}$; body, width, $.69 \mathrm{~mm}$; cornicles, .052mm.; cauda, .055mm.; antennæ, joint III, .570mm.; joint IV, $.286 \mathrm{~mm}$; joint V, .250mm; joint VI, .117mm.; filament, .076mm.

Described from specimens collected October 25, 1912. Oakland Cal., on Q. robur L.

Pupa of winged viviparous female: Pale green, wing-pads, white; dorsal tubercles absent; abdomen, armed with slender capitate spines; cornicles, slightly dusky.

Oviparaus female: Pale lemon yellow; posterior half of the body with a pinkish or orange-colored tinge; eyes, red; antenne half as long as the body, pale; distal half of joints IV to VI and apex of joint III, black; filament, dusky; tarsi brown; hind tibiæ, somewhat swollen; caudal segments of the abdomen drawn out into a conical tube; cornicles, concolorous with the body or somewhat dusky, varying in degree 
of duskiness, as wide at the base as long; cauda, pale, globular, as long as cornicles; cephalic margin of head with four capitate hairs; margin of abdomen with a few short capitate spines; beak, pale, tip brown, extending beyond hind margin of prosternum. Measurements: Body, length, $2.45 \mathrm{~mm}$; body, width, $1.12 \mathrm{~mm}$; cornicles, $.066 \mathrm{~mm}$.; cauda, .060mm.; antennx, joint III, .410mm.; joint IV, .205mm.; joint $V$, $.175 \mathrm{~mm}$; joint VI, $.133 \mathrm{~mm}$; f filament, $.130 \mathrm{~mm}$. On some specimens (the older ones) the orange-colored abdomen is very pronounced.

Described from six specimens collected November 12, 1912. Oakland, Cal., on $Q$. robur $\mathrm{L}$.

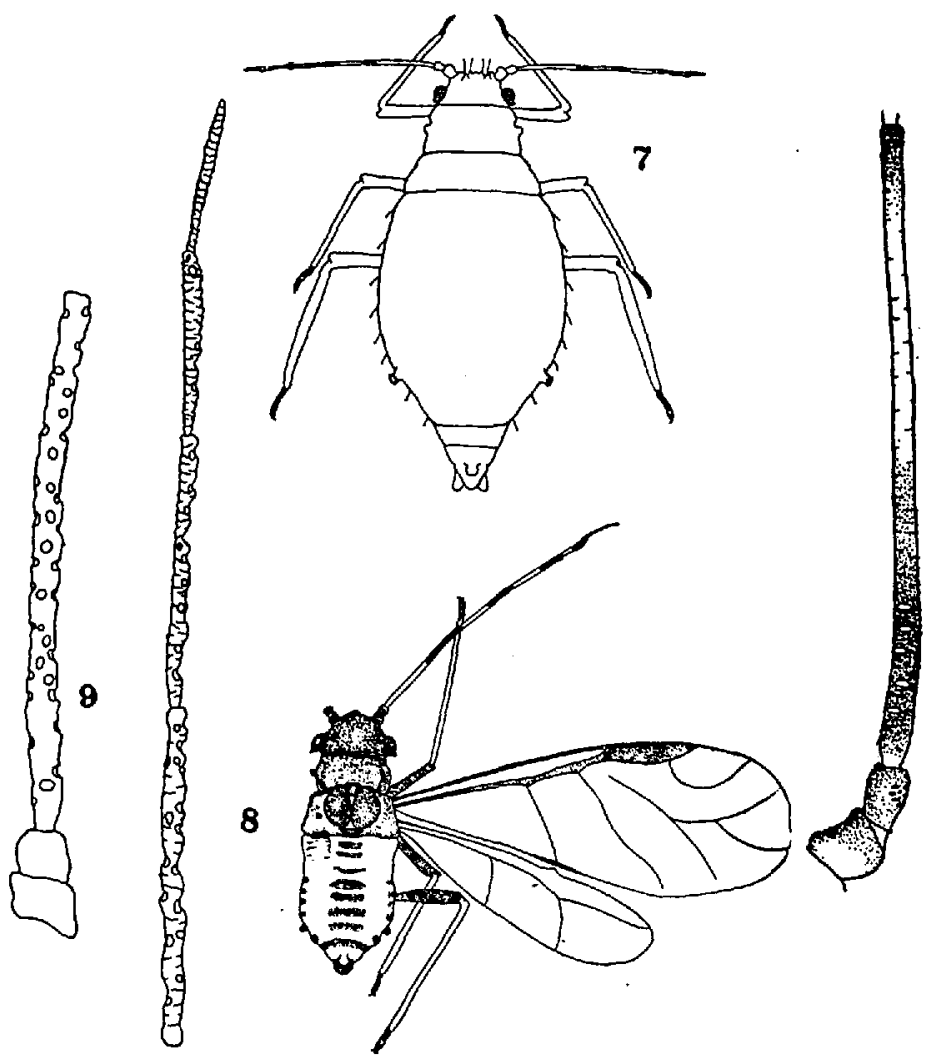

Fig. 3, Myzocallis quercus (?); 7, oviparous female; 8 , winged male; 9 , winged male, antenna.

Tinged male: General color, pale yellowish-green; eyes, bright red; basal points of antennæ pale, distal joints, dusky or black; head, prothorax, last two abdominal segments, dark green, olivaceous; thoracic lobes, scutellum, cornicles, and seven transverse bars on abdominal dorsum, black; a row of black spots on each side of the abdomen; veins of wings narrow, brown; stigma, brown; stigmatic vein, entire; discoidals I and II, thick; legs, pale greenish-yellow; femora and tarsi, dusky brown. Sensoria as follows; III, 27-30; IV, 8-10; V, 9, 10; VI, 4, 5. Measurements: Body, length, $1.33 \mathrm{~mm}$; body, width, .47mm.; wing expanse, $4.40 \mathrm{~mm}$.; cornicles, $.028 \mathrm{~mm}$; 
cauda, .0316mm.; antennæ, joint III, .512mm.; joint IV, .297mm.; joint V. .255mm.; joint VI, .143mm.; filament, .145mm.

Described from four specimens collected October 25, 1912. Oakland, Cal., on Q. robur $\mathrm{L}$.

I include this plant louse in this article in the hope that some aphidist can help me in the determination of the species. I can not identify it with any American louse and conclude that the species is European as it occurs only on oaks imported from Europe. The aphid seems to approach Myzocallis quercus Kalt. and I have listed it under this name in former papers (Journal Econ. Ent. August, '09 and August, '10). Also it is not this species, but another, that infests the native oaks.

Monellia caryella Fitch. Infests the under side of the leaves and the nuts of Juglans californica Watson. Collected at San José and Walnut Creek, Cal. Kindly determined by Prof. H. F. Wilson.

Aphis hougtonensis Throop. What seems to be this species infests and curls the terminal leaves of wild currant (Ribes sanguineum Pursh.) in the canyons of the hills of Contra Costa Co., Cal.

Aphis frigido Oestl.

Stem mother: Black or very dark green, covered with fine white bloom and short capitate hairs or spines. Antennæ black, reaching to base of cauda; joints II and III (except apex) yellowish-brown; eyes, black; first antennal joint somewhat gibbous;

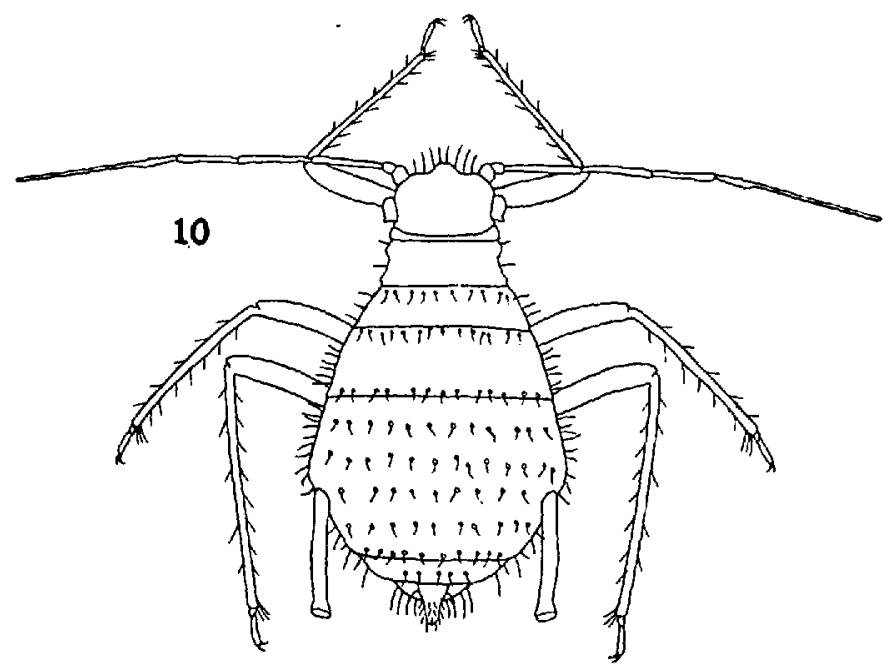

Fig. 4, Aphis frigida; stem mother (unshaded).

prothorax, with small blunt lateral tubercles; legs, black; anterior femora, yellowishbrown; cornicles, black, nearly four times as long as the cauda, their apices conspicuously flaring; cauda, dark green, ensiform. The young individuals are pale green with white pulverulence. Measurements: Body, length, $1.57 \mathrm{~mm}$.; body, width, 
$.87 \mathrm{~mm}$.; cornicles, .443mm.; cauda, .130mm.; antennæ, joint III, .26mm.; joint IV, $.25 \mathrm{~mm}$; ; joint V, .236mm.; joint VI, .125mm.; filament, .443mm.

Collected singly on Artemisia californica Less. at Walnut Creek, Cal., April 8, 1913. Colonies of Macrosiphum frigidce Oestl., were present on the same plants. This latter species is never pulverulent.

Aphis atriplicis L.

Stem mother: General color, pale green; body covered with rather sparse white bloom; body, elongate-oval; head, eyes, legs, antennx, cauda and cornicles, black or dark brown. Cornicles slightly exceeding antennal joint $\mathrm{V}$ in length, not much widened in the middle, somewhat curved. Cauda, tapering. Mersurements: Body, length, $2.42 \mathrm{~mm}$; body, width, $1.10 \mathrm{~mm}$; cornicles, $.097 \mathrm{~mm}$; cauda, $.136 \mathrm{~mm}$; antennal joint III, $.186 \mathrm{~mm}$; joint VI, $.077 \mathrm{~mm}$; ; joint $V, .088 \mathrm{~mm}$; jo int VI, .088mm.; filament, $.126 \mathrm{~mm}$.

Described from scveral specimens collected April 7, 1913, Walnut Creek, Cal., in curled leaves of Chenopodium murale L. and C. album L.

Aphis bakeri Gillette. During the fall and winter months I have collected this species in abundance on a large variety of plants, mostly Compositæ. It occurs on sunflowers, artichokes, Gnapha-

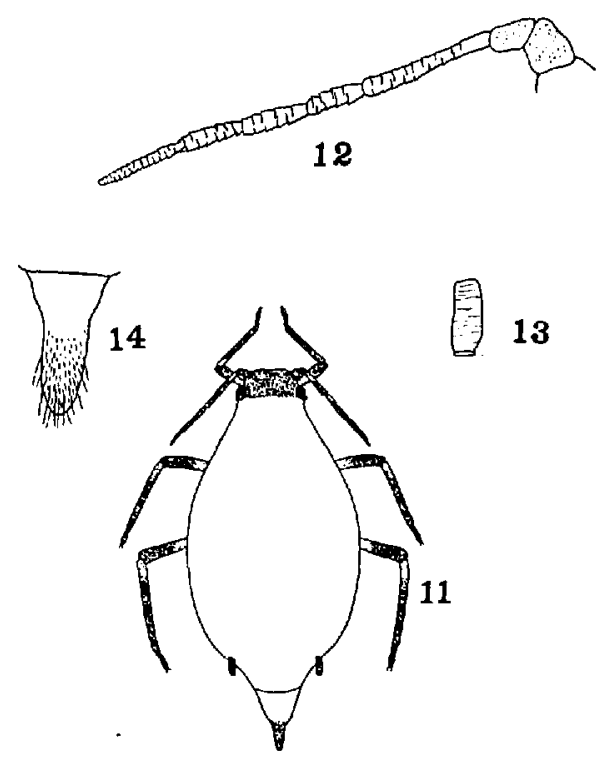

Fig. 5, Aphis alriplicis; 11, stem mother; 12, antenna; 13, cornicle; 14, cauda, of stem mother. lium, Senecio, Artemisia, Anthemis and Amsinckia. It seems peculiar that a species inhabiting legumes and pomaceous fruits east of the Sierra Nevada Mountains, should have such a different range of foodplants on the Pacific Coast. I have never found this louse on either pomaceous fruits or clovers in California. Prof. H. F. Wilson ${ }^{1}$ reports it from both these hosts in Oregon. The summer life history of the louse in California has yet to be fully studied. On German Ivy (Senecio sp.), at least, it seems to exist the year around and the annuals are infested by migrants from it. I am indebted to Messrs. J. J. Davis and H. Morrison for the determination of this species.

Hyadaphis xylostei Schank. Syn. Hyadaphis conii Davidson.

1 Biennial Crop Pest and Horticultural Report 1911-1912, Oregon Agricultural College Experiment Station, p. 89. 
(Siphocoryne conii Davidson "Notes on the Aphididæ in the vicinity of Stanford University;" Journal Econ. Ent. August, 1909). Close examination of specimens coupled with field observations have satisfied me that the species on Conium maculatum described by me as new is identical with the European honey-suckle louse.

Rhopalosiphum nervatum Gillette. A very abundant rose louse at Walnut Creek, Cal., attacking both wild and cultivated roses. I am indebted to Prof. C. P. Gillette for the determination of this species.

Rhopalosiphum corylinum sp. nov.

Winged viviparous female: General color, apple green; head and thoracic lobes, dark green; the former, with a brownish tinge; prothorax, darker than abdomen,

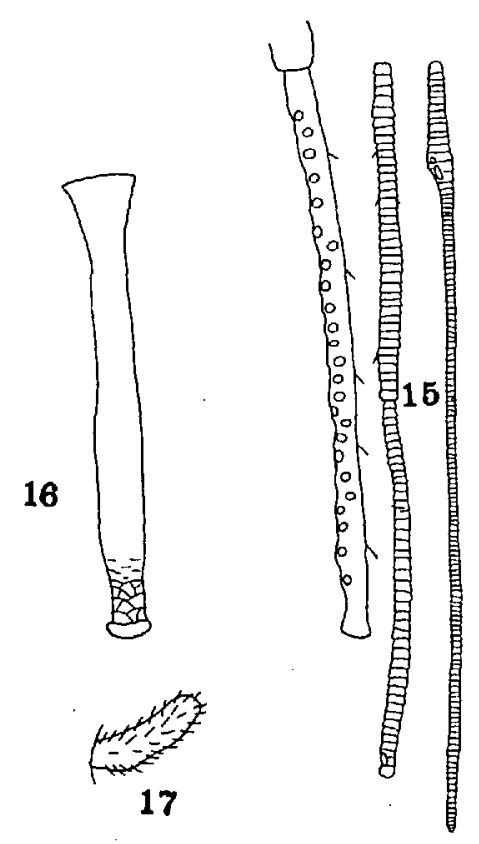

Fig. 6, Rhopalosiphum corylinum; winged viviparous female; 15 , antenna; 16, cornicle; 17, cauda (from side). but not so dark as head and thoracic lobes; seutellum, dark green; antenna, longer than the body, on frontal tubercles, dusky green; joints I, II and extreme base of III, pale green; eyes, dark red; wings, of moderate size, venation normal; stigma, long and narrow, pale greyish-green; veins, dark brown; legs, pale green; femoral and tibial apices and tarsi, dusky grey; cornicles, nearly one-third the length of the body, slightly enlarged at distal two-thirds, base, pale; apical, two-thirds dusky; cauda tapering, the apcx upturned, pale green; beak, reaches beyond second coxse. Sensoria: Joint III, twenty-four to thirty, small, disposed along almost the entire length of the joint, circular; usual apical ones on joints $\mathrm{V}$ and VI. Measurements: Body, length, $2.16 \mathrm{~mm}$.; body, width, $.83 \mathrm{~mm}$; cornicles, $.63 \mathrm{~mm}$; cauda, $.19 \mathrm{~mm}$; antennæ, III, $.80 \mathrm{~mm}$; IV, .47mm.; $\mathrm{V}, .50 \mathrm{~mm}$; $\mathrm{VI}, .143 \mathrm{~mm}$; filament, $.83 \mathrm{~mm}$. Described from many individuals.

The pupa, winged viviparous female: Pale green with a dorsal longitudinal stripe of darker green; antennæ, as long as body; articulations and whole of joints VI and filament dusky; elsewhere pale greenish-white; head, dark green; wing-pads, white; abdomen, often with orange-colored areas; cornicles, slightly thickened at distal two-thirds, pale greenish-white; legs, white; tarsi, dusky; cauda, pale, conical. Length of body, $2.44 \mathrm{~mm}$.; cornicles, $.57 \mathrm{~mm}$. Described from numerous specimens. The apterous form is pale greenish-white.

This species infests the under side of the leaves and the terminal shoots of wild hazelnut (Corylus rostrata Ait.). Collected May 20, 1913, near Walnut Creek, Cal. 


\section{Myzus fragcefolii Ckll.}

Otiparous female: General color, pale lemon yellow; older individuals, pale orange; Body spindle-shaped; antenna reach base of cornicles, pale; two distal joints, dusky. eyes, very dark red; head, paler than the rest of the body with whitish powdery covering; whole body armed with short capitate spines; cornicles long, slender, slightly curving near the apex, cylindrical, white, the tip dusky; cauda, short, tapering, dusky. Measurements: Body, length, $1.42 \mathrm{~mm}$.; body, width, .66mm.; cornicles, $.336 \mathrm{~mm}$; cauda, .130mm.; antennæ, joint I, .088mm.; joint II, .051mm.; joint III, $.314 \mathrm{~mm}$; ; joint $\mathrm{IV}$, .200mm.; joint $\mathrm{V}$, $.193 \mathrm{~mm} . ;$ joint VI, $.080 \mathrm{~mm}$; filament, $.387 \mathrm{~mm}$. Described from many specimens.

Winged male: Head and thorax, black; abdomen, dark red with sparse whitish bloom and darker cross-bands on the

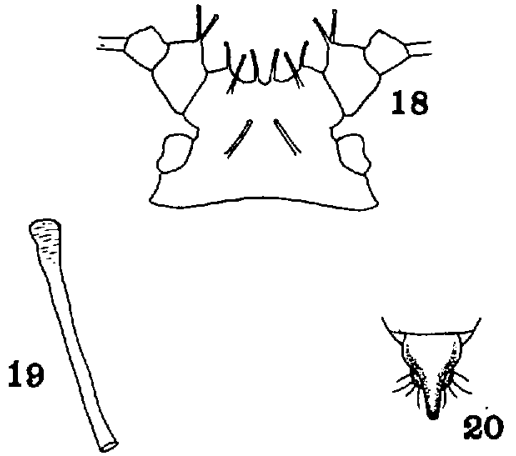

Fig. 7, Myzus fragafolii; oviparous female; 18 , head; 19 , cornicle; 20 , cauda. dorsum; cyes and antenna, black; dorsum of meso-thorax with white bloom; frontal tubereles and first antennal joint, porrect; front margin of head prominent; wings, extending far beyond abdomen; stigma, short, rather broad, white; second fork of third discoidal equidistant from first fork and wing apex; first fork equidistant from wing apex and origin of third discoidal; stigmatic vein short, curved deeply; insertions

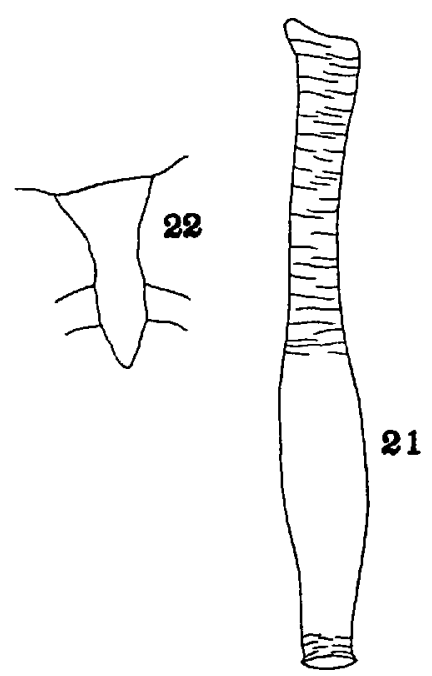

Fig. 8, Amphorophora rubicola; winged viviparous female; 21 , cornicle; 22 , couda. white; legs, pale yellowish-brown; knees, tarsi, base and apex of tibia, black; cornicles, long, narrow, cylindrical, dusky; cauda, one-third as long as cornicles, dusky, tapering. Sensoria as follows: Antennal III, about twenty small, irregularly disposed; antennal IV, about six similar; antennal V and VI, usual terminal. Measurements: Body, length, $1.20 \mathrm{~mm}$.; body, width, .43mm.; cornicles, $.32 \mathrm{~mm}$; cauda, .11mm.; wing expanse $5.54 \mathrm{~mm}$.; antennx, joint III, .420mm.; joint IV, .254mm.; joint V, .254mm.; joint VI, .121mm.; filament, $.478 \mathrm{~mm}$. Described from two specimens. Eggs: Black, shining, elongate, size $.58 \mathrm{~mm} . \times 24 \mathrm{~mm}$.

The sexed forms were observed in January and February, 1913, and were the predominant form during these months. The oviparous females far outnumbered the males. Eggs were deposited during these months on the lower surface of the strawberry leaves, and these hatched in March. At Walnut Creek, Cal., the species was observed to infest leaves and tender stalks of cultivated strawberries. 
Phorodon galeopsidis Kalt. Infesting the under side of the leaves of Polygonum sp. Collected July 25, 1912, at San Jose, Cal.

Amphorophora rubicola Oestl.

Collected on the leaves and terminal shoots of thimble-berry (Rubus nutkanus Moc.), May 13, 1913, in hilly canyons of Contra Costa Co., Cal. At that date about 95 per cent. of the lice were large pupæ or recently transformed adults. The dusky spot at the apex of the wing, mentioned by Oestlund (Synopsis of the Aphididæ of Minnesota, 1887) was present in all alate specimens examined.

Macrosiphum ludoviciance Oestl. What I take to be this species was observed infesting Artemisia heterophylla. The lice appeared first about February 6, 1913, at which date the plants were about eight inches in height. Toward the end of the month winged forms were produced and these migrated to other plants, the original centre of infestation in the area of plants under observation being canfined to one plant. Several plants were destroyed by the lice settling in masses on the growing stalk but finally towards the end of April all. the lice either left the area of plants under observation or were dostroyed by enemies. Locality: Walnut Creek, Cal.

Macrosiphum rudbeckice Fitch. This louse in California seems to confine itself to the teasel (Dipsacus fullonum L.). I have collected it on many occasions in the vicinity of San Jose, California.

\section{Additional Explanation of Figures}

Camera lucida drawings, nos. 1, 2, 4, 9, 12, 13, 14, 15, 16, 17, 18, 19, 20, 21, 22-eyepiece no. 1 , objective $16 \mathrm{~mm}$; nos. $3,5,6$-eyepiece no. 1 (tube $170 \mathrm{~mm}$.), objective $16 \mathrm{~mm}$.; nos. 7, 8, 11-eyepiece 1, objective 3in.; fig. 10-eyepiece no. 1 (tube $170 \mathrm{~mm}$.), objective 3 in.

\section{THE LIFE HISTORY OF THE SUGAR-BEET ROOT-LOUSE (PEMPHIGUS BETAE DOANE) ${ }^{1}$}

\section{By J. R. Pakker, Montana Experiment Station}

Considering how scanty is the knowledge of life histories in the genus Pemphigus, it is thought worth while to set before the entomological public the life history of the economically important species, Pemphigus betee Doane. This species is the most important pest of the sugar beet in Montana and each year does considerable injury, the tonnage in badly infested fields sometimes being reduced a third. A study of its life history was begun as an Adams project in 1909, but not until the past summer were all the stages in its complex life cycle known.

1 The investigations upon which this paper is based were carried on at the Montana Experiment Station as an Adams project under the direction of Professor R. A. Cooley, Station Entomologist. 